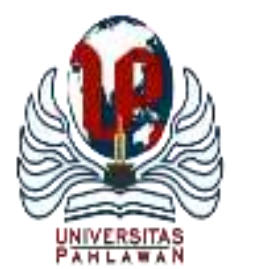

Edukatif : Jurnal Ilmu Pendidikan Volume 4 Nomor 1 Tahun 2022 Halm 474 - 486 EDUKATIF: JURNAL ILMU PENDIDIKAN

Research \& Learning in Education

https:/ledukatif.org/index.php/edukatif/index

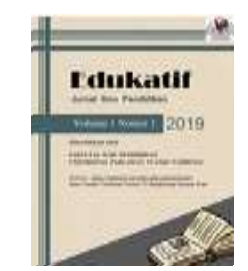

\title{
Analisis Tindak Tutur Direktif dalam Film Nanti Kita Cerita Tentang Hari Ini (NKCTHI) dan Pemanfaatannya Sebagai Bahan Ajar Teks Persuasi
}

\author{
Joty Islamiati $^{1 凶}$, Oding Supriadi ${ }^{2}$, Sinta Rosalina $^{3}$ \\ Universitas Singaperbangsa Karawang, Indonesia ${ }^{1,2,3}$

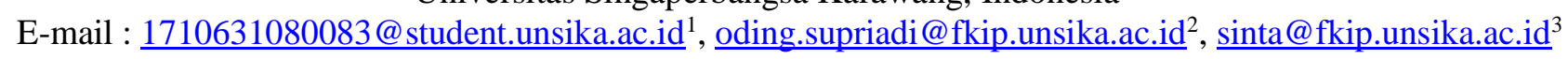

\begin{abstract}
Abstrak
Penelitian ini dilatarbelakangi oleh banyak ditemukannya peristiwa tindak tutur direktif yang terdapat dalam film Nanti Kita Cerita Tentang Hari Ini (NKCTHI). Tujuan dari penelitian ini adalah mendeskripsikan bentuk dan fungsi tindak tutur direktif yang terdapat dalam film "Nanti Kita Cerita Tentang Hari Ini (NKCTHI)" yang disutradarai oleh Angga Dwimas Sasongko, serta memanfaatkan hasil penelitian sebagai bahan ajar teks persuasi kelas VIII Sekolah Menengah Pertama (SMP). Dalam penelitian ini menggunakan pendekatan kualitatif dan metode deskriptif kualitatif. Dalam analisis data penelitian ini menggunakan metode padan pragmatis yaitu metode untuk mengidentifikasi kebahasaan akibat reaksi yang timbul pada mitra tutur ketika kebahasaan tersebut dituturkan oleh penutur (Kesuma, 2007), dengan menganalisis tindak tutur direktif, menggolongkan setiap tuturan direktif berdasarkan bentuk dan fungsi direktifnya, dan mendeskripsikan konteks tuturannya. Hasil penelitian ini ditemukan 131 data tuturan yang mengandung tindak tutur direktif, lalu digolongkan berdasarkan bentuk direktifnya yaitu bentuk perintah berjumlah 45 data tuturan, bentuk permintaan berjumlah 37 data tuturan, bentuk ajakan berjumlah 15 data tuturan, bentuk nasihat berjumlah 18 data tuturan yang memiliki fungsi direktif seperti, bentuk kritikan berjumlah 10 data tuturan, bentuk larangan berjumlah 6 data tuturan. Kemudian dari hasil penelitian tersebut dimanfaatkan sebagai bahan ajar materi teks persuasi kelas VIII.
\end{abstract}

Kata Kunci: Tindak Tutur Direktif, Film Nanti Kita Cerita Tentang Hari Ini (NKCTHI), Bahan Ajar.

\begin{abstract}
This study was motivated from the directive speech act events from "Nanti Kita Hari Ini (NKCTHI)" Film's directed by Angga Dwimas Sasongko. The aims of this study are to describe the form and function of the directive speech acts from "Nanti Kita Cerita tentang Hari Ini (NKCTHI)" film's directed by Angga Dwimas Sasongko, and the result of this research in the using as a subject materials persuasive text in the second grade of Junior High School. This study used a qualitative approach and qualitative descriptive as the methods. The results of this study found 131 speech data that showed some of directive form, the imperative form consists of 45 speech act data, the request form consists of 37 speech act data, the invitation form consist of 15 speech act data, the advice form consist of 18 speech act data, the criticism form consist of 10 speech act data, and the prohibition form consist of 6 speech act data. As the conclude, the result of this researh will be used as subject material of persuasion text in second grade of Junior High School.
\end{abstract}

Keywords: content, formatting, article.

Copyright (c) 2022 Joty Islamiati, Oding Supriadi, Sinta Rosalina

$\triangle$ Corresponding author

Email : jotyislamiati16@gmail.com

DOI : https://doi.org/10.31004/edukatif.v4i1.1821

ISSN 2656-8063 (Media Cetak)

ISSN 2656-8071 (Media Online)

Edukatif : Jurnal Ilmu Pendidikan Vol 4 No 1 Tahun 2022 p-ISSN 2656-8063 e-ISSN 2656-8071 


\section{PENDAHULUAN}

Bahasa berperan penting dalam dunia sastra. Hal ini karena bahasa mempunyai pengaruh dalam perkembangan dunia sastra karena terdapat beragam bahasa lain yang dapat kita pelajari didalamnya sekaligus dapat digunakan sebagai ilmu pengetahuan yang bermanfaat untuk perkembangan bahasa. Bahasa memiliki arti dan peranan penting bagi manusia ketika melakukan sebuah komunikasi dengan sesamanya (Saputri \& Rahmawati, 2020). Proses komunikasi pada manusia dapat terjadi melalui komunikasi verbal dan komunikasi nonverbal. Fungsi Bahasa dalam hal ini jelas sebagai alat komunikasi antar manusia, maka penulis mengaitkan penelitian ini pada bidang kajian pragmatik. Pragmatik pada dasarnya sebagai cabang ilmu bahasa yang mempelajari bagaimana satuan-satuan kebahasaan dikomunikasikan untuk mengungkapkan maksud yang melatar belakangi sebuah tuturan.

Menurut Yule dalam Cutting menyatakan; "Pragmatics and discourse analysis study the meaning of words in context, analysis the parts of meaning that can be exragmatics and discourse analysis study the meaning of words in context, analysis the parts of meaning that can be explained by knowledge of the physical and social world, and the socio psychological factors influencing communication, as well as the knowledge of the time and place in which the worlds are uttered or written", yang diartikan pragmatik dan analisis wacana adalah ilmu tentang makna ujaran pada konteksnya, yang menganalisis bagian-bagian makna yang dapat dijelaskan oleh pengetahuan fisik dan ilmu sosial, bukan hanya faktor psikologi sosial yang dapat mempengaruhi cara berkomunikasi, tetapi juga keadaan waktu dan tempat dimana tuturan tersebut diucapkan atau dituliskan. Pragmatik sebagai telah mengenai makna tuturan (utterance) menggunakan makna yang terikat konteks. Memperlakukan bahasa secara pragmatik ialah memperlakukan bahasa dengan mempertimbangkan konteksnya, yakni penggunaannya pada peristiwa komunikasi (Hirata, n.d.). pragmatik merupakan cabang linguistik yang mengkaji bahasa dari sisi pemakaiannya dalam berkomunikasi (Bambang et al., 2021).

Tindak tutur sebagai wujud peristiwa komunikasi bukanlah peristiwa yang terjadi dengan sendirinya, melainkan mempunyai fungsi, mengandung maksud, dan tujuan tertentu serta dapat menimbulkan pengaruh atau akibat pada mitra tutur. Dalam sebuah kegiatan tindak tutur, manusialah yang berperan penting dalam sebagai pemberi informasi yang disebut penutur dan penerima informasi disebut petutur atau mitra tutur, dan melibatkan antara penutur dan dua orang atau lebih yang menjadi mitra tuturnya (Nuryatin \& Artikel, 2015). Suatu tuturan merupakan sebuah ujaran atau ucapan yang berfungsi tertentu di dalam komunikasi, artinya ujaran atau tuturan mengandung maksud. Maksud tuturan sebenarnya harus diidentifikasi dengan melihat situasi tutur yang melatarbelakanginya, dalam menelaah maksud tuturan situasi penelaahan yang tidak memperhatikan situasi tutur akan menyebabkan hasil yang keliru (Nuryatin \& Artikel, 2015). Pada kegiatan tindak tutur, setiap tuturan memiliki kategori tindak tutur tertentu sesuai dengan fungsi dan penyampaiannya. Peneliti menggunakan teori "Speech acts: an essay in the philosophy of language" menyempurnakan teori mengenai tindak tutur terdahulu dan mengklasifikasikan tuturan-tuturan yang ada dibagi menjadi tiga jenis yaitu, tindak tutur lokusi, ilokusi dan perlokusi. (Rahardi, 2003) menggolongkan tindak tutur ilokusi dalam aktivitas bertutur itu ke dalam 5 macam bentuk tuturan yang masing-masing memiliki fungsi komunikatifnya sendiri-sendiri, diantaranya: a) Asertif (assertives); menyatakan, menjelaskan, menginformasikan sesuatu, mengeluh, dan meyakinkan, b) Direktif; melarang, memerintah, memohon, menasihati, menyarankan, mengkritik, c) Ekspresif; berterima kasih, memberi selamat, meminta maaf, menyalahkan, memuji, dan berbelasungkawa, d) Komisif; berjanji, bersumpah, menawarkan, kesanggupan dan mengancam, e) Deklaratif; memutuskan, melarang, memecat, dan menghukum.

Situtuasi lingkungan dalam arti lebih luas yang memungkinkan peserta pertuturan untuk dapat berinteraksi dan yang membuat ujaran mereka dapat dipahami, sehingga dapat disimpulkan bahwa konteks adalah situasi yang terjadi dalam peristiwa tutur dan dapat memengaruhi arti dalam sebuah tuturan; faktor- 
faktor yang melatar belakangi terjadinya tuturan (BERTASBIH \& UMAM, 2017). Peristiwa tindak tutur tidak akan lepas dari konteks tuturannya, konteks merupakan lingkungan disekitar tuturan yang memungkinkan peserta tutur untuk berinteraksi dalam peristiwa komunikasi dan membuat bentuk kebahasaan yang digunakan dalam interaksi itu dapat dimengerti (Wibowo, 2018). Chaer \& Agustina (2010) menjelaskan bahwa dalam peristiwa tutur, penutur selalu mempertimbangkan faktor-faktor yang mengambil peran dalam peristiwa tutur yang disebut dengan komponen tutur. Komponen tutur ini dapat diungkapkan sebagai singkatan SPEAKING yang masing-masing merupakan fonem awal dari faktor-faktor yang dimaksudkan sebagai berikut: S: Setting and scene (Latar), P: Participant (Peserta), E: Ends (Tujuan), A: Act Sequences/alur pesan, K: Key (Kunci), I: Instrument (Sarana), N: Norms (Norma), G: Genre (Jenis). Dengan adanya konteks tuturan tersebut, maka dapat memudahkan untuk memahami maksud dari sebuah tuturan Penelitian ini berfokus pada tindak tutur yang sangat berkaitan erat dengan bahasa dan sastra.

Komunikasi merupakan sistem simbol lisan yang bersifat arbriter yang digunakan oleh suatu anggota masyarakat bahasa untuk berinteraksi antar sesama (Darwowidjojo, 2008). Tindak tutur direktif selain ditemukan dalam komunikasi sehari-hari, juga dapat ditemui dalam kehidupan sehari-hari, tetapi juga terdapat dalam percakapan film (BERTASBIH \& UMAM, 2017). Dalam sebuah film terjadi interaksi komunikasi antar tokohnya. Tokoh yang terdapat di dalam film menyampaikan maksud dan pesan melalui percakapan-percakapan. Dialog berhubungan dengan tuturan yang mengacu pada tindak tutur pragmatik (Widyawati, 2019). Para tokoh dalam film melakukan interaksi berupa komunikasi dengan tokoh lain. Komunikasi tersebut tertuang dalam sebuah dialog. Dialog yang dilakukan para tokoh dalam film adalah menyampaikan informasi berupa pikiran, maksud, dan perasaan baik secara langsung maupun tidak langsung (Rahma, 2018). Di dalam percakapan tersebut tekandung adegan, setting, dan topik pembicaraan tertentu yang merupakan bagian dari konteks tuturan.

Peneliti menemukan proses tindak tutur yang relevan dengan kehidupan berbahasa melalui Film "Nanti Kita Cerita Tentang hari ini” yang disutradarai oleh Angga Dwimas Sasongko, dalam perusahaan produksi Visinema Pictures, merupakan sebuah film drama keluarga yang di adaptasi dari sebuah novel berjudul "Nanti Kita Cerita Tentang Hari Ini” karya Marcella FP, tayang pada awal tahun 2020 tepatnya pada tanggal 2 Januari 2020. Film yang disutradarai oleh Angga Dwimas Sasongko ini menjadi perbincangan banyak kalangan, karena terdapat makna dan hal positif tentang kehidupan, yang membuat film tersebut menjadi disukai oleh masyarakat, hingga menembus 2 Juta lebih penonton dalam selama penayangan. Dalam film ini terdapat banyak hal-hal positif yang dapat diambil seperti, penyuguhan realita dengan berbagai persoalan yang terjadi pada lingkungan keluarga, memberi pesan bahwa kebahagiaan didalam keluarga dapat berawal dari sebuah kesederhanaan dan kebersamaan. Peneliti menggunakan film tersebut untuk dijadikan subjek penelitian, karena terdapat banyak dialog dalam film tersebut yang mengandung tindak tutur ilokusi direktif yang menjadi fokus penelitian ini.

Hasil dari penelitian ini dapat dimanfaatkan dalam pembuatan bahan ajar berupa handout, untuk menambah pengetahuan peserta didik mengenai tindak tutur direktif yang erat kaitannya dengan kebahasaan teks persuasi. Handout dapat diartikan sebagai ringkasan bahan pembelajaran cetak yang di dalamnya terdapat pemetaan konsep, uraian singkat, ikhtisar, skema, prosedur kerja, penerapan rumus-rumus, dan contoh-contoh perhitungan yang di distribusikan secara gratis kepada siswa (Yaumi, 2018). Menurut Nana Syahodin dan Erliana (2012) handout bermanfaat sebagai pegangan dasar bagi guru dan siswa untuk memperdalam pembelajaran baik pembelajaran di kelas maupun di luar kelas. Dalam pembelajaran jarak jauh, handout sangat berguna sekali untuk siswa karena dapat membantu siswa untuk memahami materi yang diajarkan, karena sifatnya yang komunikatif dan mudah untuk dipelajari berulang-ulang (Islamiati et al., 2020). 
477 Analisis Tindak Tutur Direktif dalam Film Nanti Kita Cerita Tentang Hari Ini (NKCTHI) dan Pemanfaatannya Sebagai Bahan Ajar Teks Persuasi - Joty Islamiati, Oding Supriadi, Sinta Rosalina DOI: https://doi.org/10.31004/edukatif.v4i1.1821

\section{METODE PENELITIAN}

Berdasarkan tujun penelitian, metode yang digunakan dalam penelitian ini adalah metode kualitatif deskriptif. Menurut (Sugiyono, 2016) metode penelitian kualitatif adalah metode pada filsafat posposotivisme, digunakan untuk meneliti pada kondisi objek yang alamiah, (sebagai lawannya adalah eksperimen) dimana peneliti adalah sebagai instrumen kunci, pengambilan sumber data dilakukan secara triangulasi (gabungan), analisis data bersifat induktif atau kualitatif dan hasil penelitian kualitatif lebih menekankan makna dari pada generalisasi. Deskriptif yang digunakan pada penelitian ini sesuai dengan ungkapan (Arikunto, 2013) bahwa penelitian deskriptif yaitu penelitian yang dimaksudkan untuk mengumpulkan informasi mengenai status suatu gejala yang ada, keadaan gejala menurut apa adanya pada saat penelitian dilakukan (Azziz et al., 2021). Deskriptif di sini menyarankan bahwa penulisan penelitian yang dilakukan berdasarkan fakta atau fenomena yang secara empiris hidup pada penuturnya, sehingga data yang dihasilkan berupa perian bahasa yang sifatnya seperti potret paparan apa adanya (Sudaryanto, 2015), karena pada penelitian ini penulis menganalisis secara langsung data penelitian berupa bentuk tindak tutur direktif yang terdapat pada percakapan antar tokoh dalam film "Nanti Kita Cerita Tentang Hari Ini (NKCTHI)". Objek penelitian ini yaitu tindak tutur direktif berdasarkan bentuk dan fungsi tindak tutur direktifnya. Sedangkan subjek penelitian ini yaitu Film "Nanti Kita Cerita Tentang Hari Ini (NKCTHI)" disutradarai oleh Angga Dwimas Sasongko produksi rumah film Visinema Picture.

Sumber data penelitian ini adalah kegiatan tuturan percakapan antar tokoh dalam film "Nanti Kita Cerita Tentang Hari Ini (NKCTHI) yang disutradarai oleh Angga Dwimas Sasongko. Instrumen penelitian yang digunakan dalam penelitian ini adalah peneliti sendiri, dan dibantu dengan alat bantu berupa rekaman film NKCTHI. Alat yang digunakan berupa perekam suara, data hasil rekam catat, laptop, buku, pulpen untuk mencatat, dan tabel indikator tindak tutur direktif yang dibuat oleh peneliti. Dalam penelitian ini metode pengumpulan data yang digunakan yaitu metode Simak Bebas Libat Cakap (SBLC). Metode simak bebas libat cakap yaitu metode yang digunakan oleh peneliti dalam mengamati penggunaan bahasa oleh informannya dan peneliti sama sekali tidak terlibat dalam peristiwa tutur yang sedang diteliti (Mahsun, 2012).

Teknik analisis data yang digunakan dalam penelitian adalah metode padan pragmatis, yaitu metode untuk mengidentifikasi kebahasaan akibat reaksi yang timbul pada mitra tutur ketika kebahasaan tersebut dituturkan oleh penutur (Kesuma, 2007). Tahap penelitian dalam penelitian in yaitu (1) Peneliti menyimak (menonton) tuturan percakapan antar tokoh dalam film "Nanti Kita Cerita Tentang Hari Ini (NKCTHI)" secara teliti dan berulang. (2) Setelah peneliti selesai menyimak, peneliti mengumpulkan data dengan cara merekam setiap percakapan dan tuturan yang terdapat dalam film NKCTHI. (3) Setelah menyimak dan merekam, data dikumpulkan dengan transkipsi data yang didapat dari hasil rekaman. Transkipsi yang dilakukan yaitu menulis data lisan menjadi tulisan, yang berupa semua tuturan tokoh dalam film NKCTHI. (4) Setelah melakukan transkip data, penulis menggunakan teknik catat, untuk memperoleh data akhir berupa tuturan yang mengandung tindak tutur direktif, dan menganalisis fungsi-fungsi yang terdapat pada tuturan yang terdapat tindak tutur direktif didalamnya. (5) Dari data tindak tutur direktif yang telah diperoleh, kemudian peneliti mengklasifikasikan tuturan direktif berdasarkan bentuk dan fungsi tindak tutur direktifnya, lalu peneliti menganalisis konteks tuturannya dan mendeskripsikan hasil data penelitian. (6) Kemudian dari hasil analisis penelitian ini dimanfaatkan sebagai bahan ajar teks persuasi di kelas VIII Sekolah Menengah Pertama (SMP).

\section{HASIL DAN PEMBAHASAN PENELITIAN}

Hasil penelitian yang didapat dan pembahasan hasil berdasarkan rumusan masalah dan tujuan penelitian, mengenai bentuk dan fungsi tindak tutur direktif dalam film"Nanti Kita Cerita Tentang Hari Ini" disutradarai oleh Angga Dwimas Sasongko, serta pemanfaatan hasil penelitian sebagai bahan ajar teks persuasi kelas VIII Sekolah Menengah Pertama (SMP). Data yang diperoleh yaitu 131 data tuturan yang 
mengandung tindak tutur direktif. Dari 131 data tuturan tersebut digolongkan berdasarkan bentuk direktifnya dan fungsi direktifnya. Berikut beberapa hasil bentuk dan fungsi tindak tutur direktif yang diperoleh, yang akan dijelaskan dari beberapa data yang didapat.

\section{Bentuk Tindak Tutur Direktif Perintah}

Terdapat 45 data tuturan, yang digolongkan berdasarkan fungsi tindak tutur direktifnya seperti, fungsi memerintah 17 data tuturan, fungsi menyuruh 19 data tuturan, fungsi mengharuskan 3 data tuturan, dan fungsi menyilakan 6 data tuturan. Dari beberapa data yang didapat, peneliti akan menjelaskan salah satu data berdasarkan fungsi direktifnya sebagai berikut.

\section{Fungsi Memerintah}

Ibu: "Kamu disini ya jaga Aurora" (kepada Angkasa)

Peristiwa tuturan terjadi pada pagi hari, di rumah sakit. Ibu sebagai penutur dan Angkasa sebagai mitra tutur. Tuturan yang disampaikan ibubertujuan untuk memerintah Angkasa agar tetap di dalam kamar dan menjaga Aurora Ketika ibu hendak melahirkan dan ayah yang menemani ibu di dalam ruang bersalin. Ketika sampai di rumah sakit dan ibu hendak memasuki ruang bersalin, dan Angkasa berada disebelah ibu. Kemudian ibu memerintah Angkasa agar tidak kemana-mana dan menjaga Aurora. Tuturan disampaiakan secara singkat dengan rasa tenang. Penyampaian tuturan secara lisan. Tuturan yang disampaikan menggunakan bahasa yang sopan, lemah lembut dalam memerintah. Tuturan berbentuk dialog. Tuturan tersebut merupakan tindak tutur direktif yang memiliki fungsi memerintah, karena pada tuturan tersebut ibu memerintah Angkasa yang masih kecil itu untuk tetap berada di kamar dan menjaga Aurora ketika ibu hendak memasuki ruang persalinan.

\section{Fungsi Menyuruh}

Ayah: "ajak aja lika ke sini ang"

Peristiwa tuturan terjadi pada malam hari di rumah. Ayah sebagai penutur dan Angkasa sebagai mitra tutur. Tuturan yang disampaikan bertujuan menyuruh angkasa untuk mengajak Lika ke rumah, untuk ikut makan malam bersama. Ketika Ayah membatalkan makan malam bersama di restoran dan pulang kembali ke rumah. Angkasa pun mengeluh "tau gitu aku pergi makan aja sama Lika", dalam tuturannya Angkasa menjelaskan kekecewaannya dia sudah membatalkan janji makan malam dengan Lika demi ikut dengan keluarga, namun pada akhirnya tidak jadi. Setelah mendengar Angkasa berbicara seperti itu, Ayah menyuruh Angkasa untuk mengajak Lika ke rumah agar ikut makan malam bersama. Penyampaian tuturan tersebut menggunakan nada perintah dengan suasana santai. Tuturan yang disampaikan secara lisan. Tuturan yang disampaikan dengan lemah lembut. Tuturan berbentuk dialog. Tuturan tersebut merupakan bentuk tindak tutur direktif perintah yang memiliki fungsi menyuruh, terlihat dari tujuan tuturan tersebut Ayah menyuruh Angkasa mengajak Lika ke rumah untuk makan malam bersama.

\section{Fungsi Mengharuskan}

Ayah: "denger ang, kalau saya minta kamu untuk jemput awan di kantor, itu artinya kamu harus jemput dia di kantor, mengerti?"

Peristiwa tuturan terjadi pada malam hari di rumah sakit. Ayah sebagai penutur dan Angkasa sebagai mitra tutur. Tuturan yang disampaikan bertujuan memerintah Angkasa dengan mengharuskannya menjemput Awan di kantor setiap harinya, bukan di tempat lain. Setelah memarahi dan menegur Angkasa karena kelalayannya telat menjemput Awan di kantor, hingga Awan mengalami kecelakaan. Ayah terusterus menunjukkan kemarahannya kepada Angkasa dan terus mengatakan memerintah agar Angkasa harus setiap hari menjemput Awan di kantor. Penyampaian tuturan menggunakan nada bicara sedang marah dan tegas. Tuturan yang disapaikan secara lisan. Penutur menunjukkan kemarahannya. Tuturan yang disampaikan berbentuk dialog. Tuturan tersebut merupakan bentuk tindak tutur direktif perintah yang 
memiliki fungsi mengharuskan, terlihat dari tujuan tuturan tersebut Ayah mengharuskan Angkasa untuk menjemput Awan di kantornya bukan di tempat lain.

\section{Fungsi Menyilakan}

\section{Pak Rifai: "Ya sok atuh taked" (Yasudah silahkan tanda tangan)}

Peristiwa tuturan terjadi pada siang hari di kantor. Pak Rifai sebagai penutur dan Awan sebagai mitra tutur. Tuturan bertujuan untuk mempersilakan Awan menandatangani kontrak jika diam au mengambil projek tersebut. Ketika pak Rifai bertanya kepada Awan tentang keputusannya mau mengambil projek tersebut atau tidak, dan awan pun berkata "mau pak" dengan kata lain Awan menerima untuk mengerjakan projek tersebut. Lalu pak Rifai berdiri dan menyilakan Awan untuk menandatanganin kontrak tersebut. Tetapi Awan meminta untuk di bawa terlebih dahulu kertas kontraknya. Tuturan yang disampaikan dengan nada yang sedikit keras. Tuturan yang disampaikan secara lisan. Tuturan yang disampaikan dengan suasana santai. Tuturan yang disampaikan berbentuk dialog. Tuturan tersebut merupakan bentuk tindak tutur direktif perintah yang memiliki fungsi menyilakan, terlihat dari tujuan tuturan tersebut Pak Rifai menyilakan dengan menggunakan bahasa daerah, agar Awan menandatangani kertas kontrak projek yang akan diambilnya.

\section{Bentuk Tindak Tutur Direktif Permintaan}

Terdapat 37 data tuturan, yang digolongkan berdasarkan fungsi tindak tutur direktifnya seperti, fungsi meminta 20 data tuturan, fungsi mengharap 1 data tuturan, fungsi memohon 3 data tuturan, fungsi menawarkan 13 data tuturan. Dari beberapa data yang didapat, peneliti akan menjelaskan salah satu data berdasarkan fungsi direktifnya sebagai berikut.

\section{Fungsi Meminta}

Kale: "Bagi dong"

Peristiwa tuturan terjadi pada siang hari di toko penjual makanan kering. Kale sebagai penutur dan Awan sebagai mitra tutur. Tuturan yang disampaikan Kale bertujuan meminta manisan permen yang Awan beli di toko tadi. Ketika Kale dan Awan mampir ke toko makanan kering, dan menyicipi sebuah manisan permen. Lalu Awan menyukai manisan tersebut dan langsung membelinya. Setelah keluar dari dari toko tersebut, Kale ingin meminta manisan tersebut dengan candaan. Penyampaian tuturan dengan santai, bercanda, dan rasa senang. Tuturan yang disampaikan secara lisan. Penyampaian tuturan sopan dan lemah lembut. Tuturan yang disampaikan berbentuk dialog. Tuturan tersebut merupakan bentuk tindak tutur direktif permintaan yang memiliki fungsi meminta, terlihat dari tujuan tuturan tersebut Kale meminta makanan manisan yang dibeli oleh Awan di toko makanan.

\section{Fungsi Mengharap}

Awan: "Yah ini ga ada urusannya sama anak orang yah. Ini anak ayah sendiri yang mau, mau naik motor, mau nikmatin rasa takutnya, mau belajar ngadepin masalahnya sendiri."

Peristiwa tuturan terjadi pada malam hari di rumah. Awan sebagai penutur dan Ayah sebagai mitra tutur. Tuturan yang disampaikan bertujuan bahwa semua yang Awan lakuin barusan adalah keinginannya sendiri untuk melawan rasa takutnya selama ini. Ketika Ayah memerintah Awan untuk menghubungi Kale untuk balik lagi kerumah dan menemui ayah, Awan merasa kesal. Karena menurutnya apa yang Awan lakukan itu semua keinginannya sendiri tidak ada urusan dengan orang lain ataupun Kale. Penyampaian tururan dengan tegas, dan rasa kesal. Tuturan yang disampaikan secara lisan. Penyampaian tuturan dengan sedikit kencang penyampaiannya. Tuturan yang disampaikan berbentuk dialog. Tuturan tersebut merupakan bentuk tindak tutur direktif permintaan yang memiliki fungsi mengharap, terlihat dari tujuan tuturan tersebut Awan berbicara kepada Ayah untuk tidak menyalahkan orang lain, karena semua yang terjadi adalah kemauan Awan sendiri. Awan berharap agar bisa menjadi orang yang bisa belajar menghadapi masalah dan ketakutannya sendiri. 


\section{Fungsi Memohon}

Awan: "ikut, ayo plis plis ikut"

Peristiwa tuturan terjadi pada siang hari di rumah. Awan sebagai penutur dan Angkasa sebagai mitra tutur. Tuturan yang disampaikan bertujuan meminta dengan sangat mohon agar Awan diperbolehkan ikut ke acara konser tersebut. Ketika Awan terus memaksa agar Angkasa mau mengajak ke acara konser tanpa izin kepada Ayah terlebih dahulu, karena menurut Awan meminta izin kepada Ayah itu percuma tidak akan diberi izin. Penyampaian tuturan dengan santai dan nada memaksa. Tuturan yang disampaikan secara lisan. Penyampaian tuturan dengan raut wajah memohon. Tuturan yang disampaikan berbentuk dialog. Tuturan tersebut merupakan bentuk tindak tutur direktif permintaan yang memiliki fungsi memohon, terlihat dari tujuan tuturan tersebut Awan memohon kepada Angkasa untuk diperbolehkan ikut ke acara konser musik.

\section{Fungsi Menawarkan}

\section{Lika: "Mau gak?"}

Peristiwa tuturan terjadi pada siang hari, di dalam ruangan tempat konser musik. Lika sebagai penutur dan Awan sebagai mitra tutur. Tuturan yang disapaikan bertujuan menawarkan permen kepada Awan. Ketika sedang asik mengobrol, tiba-tiba Lika mengekuarkan permen dan menawarkannya kepada Awan ingin juga atau tidak. Tuturan yang disampaikan dengan santai dan singkat. Tuturan yang disampaikan secara lisan. Penyampaian tuturan menggunakan bahasa yang baik. Tuturan yang disampaikan berbentuk dialog. Tuturan tersebut merupakan bentuk tindak tutur direktif permintaan yang memiliki fungsi menawarkan, terlihat dari tujuan tuturan tersebut Lika menawarkan dan memberikan sebuah permen kepada Awan yang sedang berdiri disampingnya.

\section{Bentuk Tindak Tutur Direktif Ajakan}

Terdapat 15 data tuturan, yang digolongkan berdasarkan fungsi tindak tutur direktifnya seperti, fungsi mengajak 13 data tuturan, dan fungsi mendesak 2 data tuturan. Dari beberapa data yang didapat, peneliti akan menjelaskan salah satu data berdasarkan fungsi direktifnya sebagai berikut.

\section{Fungsi mengajak}

Angkasa: "Ra ikut yuk"

Peristiwa tuturan terjadi pada siang hari di rumah. Angkasa sebagai penutur dan Aurora sebagai mitra tutur. Tuturan yang disampaikan bertujuan Angkasa mengajak Aurora agar ikut juga ke acara konser musiknya. Ketika menunggu Awan yang sedang bersiap-siap, dan Aurora sedang berada di dalam studionya. Kemudiam Angkasa menghampiri dan mengajak Aurora untuk ikut bersamanya. Dengan nada gembira. Tuturan yang disampaikan secara lisan. Penyampaian dengan wajah yang santai. Tuturan yang disampaikan berbentuk dialog. Tuturan tersebut merupakan bentuk tindak tutur direktif ajakan yang memiliki fungsi mengajak, karena dari tujuan tuturan tersebut Angkasa mengajak Aurora untuk ikut pergi bersama dengan Angkasa dan Awan, untuk pergi ke konser musik yang salah satu bandnya adalah kegemaran Aurora. Namun Aurora menolak untuk ikut.

\section{Fungsi mendesak}

Angkasa: "Ra ikut yuk"

Peristiwa tuturan terjadi pada siang hari di rumah. Angkasa sebagai penutur dan Aurora sebagai mitra tutur. Tuturan yang disampaikan bertujuan Angkasa mengajak Aurora agar ikut juga ke acara konser musiknya. Ketika menunggu Awan yang sedang bersiap-siap, dan Aurora sedang berada di dalam studionya. Kemudiam Angkasa menghampiri dan mengajak Aurora untuk ikut bersamanya. Dengan nada gembira. Tuturan yang disampaikan secara lisan. Penyampaian dengan wajah yang santai. Tuturan yang disampaikan berbentuk dialog.

Tuturan tersebut merupakan bentuk tindak tutur direktif ajakan yang memiliki fungsi mengajak, karena dari tujuan tuturan tersebut Angkasa mengajak Aurora untuk ikut pergi bersama dengan Angkasa dan 
481 Analisis Tindak Tutur Direktif dalam Film Nanti Kita Cerita Tentang Hari Ini (NKCTHI) dan Pemanfaatannya Sebagai Bahan Ajar Teks Persuasi - Joty Islamiati, Oding Supriadi, Sinta Rosalina DOI: https://doi.org/10.31004/edukatif.v4i1.1821

Awan, untuk pergi ke konser musik yang salah satu bandnya adalah kegemaran Aurora. Namun Aurora menolak untuk ikut.

\section{Bentuk Tindak Tutur Direktif Nasihat}

Terdapat 18 data tuturan, yang digolongkan berdasarkan fungsi tindak tutur direktifnya seperti, fungsi menasihati 2 data tuturan, fungsi menyarankan 3 data tuturan, fungsi mengimbau 3 data tuturan, fungsi menyerukan 2 data tuturan, dan fungsi mengingatkan 8 data tuturan. Dari beberapa data yang didapat, peneliti akan menjelaskan salah satu data berdasarkan fungsi direktifnya sebagai berikut.

\section{Fungsi Menasihati}

Ibu: "Mas angkasa, marah itu wajar nak. Tapi jangan biarkan marah itu jadi satu-satunya jalan keluar kalau ada masalah"

Peristiwa tuturan terjadi pada siang hari di rumah. Ibu sebagai penutur dan Angkasa sebagai mitra tutur. Tuturan yang disampaikan bertujuan memberikan nasihat kepada Angkasa tentang bagaimana mengontrol emosi saat sedang marah dan kesal. Setelah bertengkar sampai memukuli Rio hingga babak belur, dan sesampainya di rumah Ayah memarahi Angkasa karena kelakuaannya dan memerintah Angkasa untuk minta maaf kepada Rio. Namun disaat yang sama Ibu menegur sambil menasihati Angkasa kalau merasakan marah itu wajar. Ibu menasihati Angkasa untuk menahan amarahnya saat ia sedang merasa kesal, karena marah bukan satu-satunya jalan keluar dari sebuah masalah kata Ibu. Kemudian setelah ayah dan ibu memarahi dan menasihati, Angkasa langsung pergi keluar dan mengendarai sepeda dengan kencang, serta rasa sedih dan kesalnya yang dia rasakan sambil berteriak. Penyampaian tuturan dengan lemah lembut dan suara yang pelan. Tuturan yang disampaikan secara lisan. Tuturan menunjukan perhatian dan kasih sayang terhadap anak. Tuturan yang disampaikan berbentuk dialog. Tuturan tersebut merupakan bentuk tindak tutur direktif nasihat yang memiliki fungsi menasihati, terlihat dari tujuan tuturan tersebut Ibu menasihati Angkasa untuk menahan dan mengontrol emosinya, ketika sedang marah.

\section{Fungsi Menyarankan}

\section{Ayah: "Gausah mandi wan, ganti baju aja"}

Peristiwa tuturan terjadi pada malam hari, di rumah. Ayah sebagai penutur dan Awan sebagai mitra tutur. Tuturan yang disampaikan Ayah bertujuan untuk menyarankan agar Awan agar tidak perlu mandi, hanya sekedar mengganti baju saja. Ketika sampai di rumah, dan orang-orang bergegas dan menunggu Awan untuk pergi makan malam bersama di restoran. Kemudian Ayah menyarankan dan menyuruh agar Awan untuk tidak perlu mandi hanya ganti baju saja. Namun Awan menjelaskan tidak dapat ikut pergi, karena harus segera menyelesaikan maket yang akan dikumpulkan esok lusa. Tuturan yang disampaikan dengan nada tergesa gesa. Tuturan yang disampaikan secara lisan. Tuturan yang disampaikan menggunakan bahasa yang sopan. Tuturan yang disampaikan berbentuk dialog. Tuturan tersebut merupakan bentuk tindak tutur direktif nasihat yang memiliki fungsi menyarankan, terlihat dari tujuan tuturan tersebut Ayah berbicara kepada Awan dan menyarakannya untuk tidak perlu mandi hanya mengganti baju saja, karena kedatangannya yang sudah telat dan semuanya harus berbegas menuju restoran untuk makan malam bersama.

\section{Fungsi Mengimbau}

Angkasa: "Hati-hati wan anak band ga ada yang bener"

Peristiwa tuturan terjadi pada malam hari, di tempat konser. Angkasa sebagai penutur dan Awan sebagai mitra tutur. Bertujuan untuk memberitahu dengan meledek Awan kalau anak-anak band hamper rata-rata tidak ada yang benar, dengan maksud jangan mudah tergoda. Ketika Angkasa menitipkan Awan kepada Kale untuk menjaganya, lalu Angkasa pun pergi sambil berbicara ambil meledek adiknya itu dengan maksud menghimbau agar jangan gampang percaya kepada laki-laki anak band. Penyampaian tuturan dengan mengejek sambil tersenyum. Tuturan yang disampaikan secara lisan. Penyampaian tuturan 
dengan suara yang sedikit kencang. Tuturan yang disampaikan berbentuk dialog. Tuturan tersebut merupakan bentuk tindak tutur direktif nasihat yang memiliki fungsi mengimbau, terlihat dari tujuan tuturan tersebut Awan berbicara dengan Awan dan mengimbaunya untuk berhati-hati dekat dengan anak band dengan penyampaian diiringi dengan maksud bercanda.

\section{Fungsi Menyerukan}

Ayah: "Angkasa tau kan? Awan juga tau kan? Kalian tau kan pameran tadi sangat penting artinya untuk Aurora. Perdebatan tadi di pameran mestinya ga perlu terjadi, kalau kamu gampang di hubungi."

Peristiwa tuturan terjadi pada malam hari di rumah. Ayah sebagai penutur, lalu ibu, Angkasa, Aurora dan Awan sebagai mitra tutur. Tuturan yang disampaikan bertujuan memberitahu kalau pameran tersebut sangat penting bagi Aurora, dan menegur Awan karna sulit dihubungi yang menjadikan adanya perdebatan tadi. Ketika semua sudah pulang ke rumah, ayah menyuruh ibu untuk mengumpulkan semua anggota keluarga di ruang tengah. Lalu ayah mulai berbicara dan berbicara tegas mengenai perdebatan di pameran yang penting bagi Aurora sebelumnya, semua menjadi kacau setelah perdebatan ayah dan Awan. Lalu ayah menegur dan memarahi Awan karna sikapnya yang berubah susah dihubungi pada saat-saat acara penting. Penyampaian tuturan dengan nada dan raut wajah marah. Tuturan yang disampaikan secara lisan. Penyampaian tuturan dengan nada tegas dan kencang. Tuturan yang disampaikan berbentuk dialog. Tuturan tersebut merupakan bentuk tindak tutur direktif nasihat yang memiliki fungsi menyerukan, terlihat dari tujuan tuturan tersebut Ayah menyerukan kepada seluruh anggota keluarga bawa acara pameran malam tadi adalah pameran yang penting bagi Aurora, yang semestinya tidak ada pertengkaran hingga merusak momen penting tersebut, jika Awan tidak datang terlambat menurut Ayah.

\section{Fungsi Mengingatkan}

Ayah: "Ayo mas, hati-hati"

Peristiwa tuturan terjadi pada pagi hari di depan rumah. Ayah sebagai penutur dan Angkasa sebagai mitra tutur. Tuturan yang disampaikan Ayah bertujuan untuk mengingatkan Angkasa agar berhati-hati pada saat berjalan bergegas menuju mobil. Saat bergegas dan berjalan menuju mobil, ayah menggendong Aurora sambil membawa tas yang berisikan baju, dan Angkasa berlari dibelakang mengikuti langkah ayah, dan ayah mengingatkan Angkasa agar berhati-hati saat melangkah menuju mobil. Penyampaian tuturan dengan halus, dan singkat. Penyampaian tuturan menggunakan bahasa yang sopan. Tuturan yang disampaikan berbentuk dialog. Tuturan tersebut merupakan bentuk tindak tutur direktif nasihat yang memiliki fungsi mengingatkan, terlihat dari tujuan tuturan tersebut Ayah berusaha mengingatkan Angkasa untuk berjalan dengan hati-hati agar tidak terjatuh.

\section{Bentuk Tindak Tutur Direktif Kritikan}

Terdapat 10 data tuturan, yang digolongkan berdasarkan fungsi tindak tutur direktifnya seperti, fungsi menegur 7 data tuturan, fungsi menyindir 1 data tuturan, dan fungsi memarahi 2 data tuturan. Dari beberapa data yang didapat, peneliti akan menjelaskan salah satu data berdasarkan fungsi direktifnya sebagai berikut.

\section{Fungsi Menegur}

Pelatih: "ra minggu lalu kamu 1 menit 30 detik loh, ra jadi nomer satu aja gak cukup. Kamu harus jadi yang terbaik di antara sekolah-sekolah lain."

Peristiwa tuturan terjadi pada siang hari di tempat pelatihan renang. Pelatih sebagai penutur dan Aurora sebagai mitra tutur. Tuturan yang disampaikan bertujuan menegur karena waktu yang dicapai Aurora lebih lambat dari minggu lalu, dan untuk mengharuskan Aurora menjadi yang terbaik dari sekolah lain pada saat lomba renang nantinya. Pada saat Aurora Latihan renang untuk melatih kecepatan renangnya karena akan mengikuti perlombaan, Ketika sampai di ujung kolam dan selesai sampai akhir kemudian pelatih menegur dan memberitahu waktu yang diperoleh Aurora lebih lambat dari minggu sebelumnya. Kemudian pelatih memberikan nasihat dan mengharuskan Aurora agar giat berlatih dan harus menjadi 
yang terbaik diantara sekolah lainnya. Tuturan yang disampaikan menggunakan nada marah dengan teguran. Tuturan yang disampaikan secara lisan. Tuturan yang disampaikan dengan gaya penyampaian yang kurang baik. Tuturan yang disampaikan berbentuk dialog. Tuturan tersebut merupakan bentuk tindak tutur direktif kritikan yang memiliki fungsi menegur, terlihat dari tujuan tuturan tersebut pelatih renang menegur Aurora ketika latihan renang untuk lomba antar sekolah, dan menegur Aurora karena kecepatan waktu renangnya lebih lambat dari minggu sebelumnya.

\section{Fungsi Menyindir}

Angkasa: "Yang ayah lakuin selama ini cuma nyalahin, menyangkal, nyuruh semua orang di keluarga ini untuk nyembunyiin luka. Pura-pura kalau ga ada apa-apa!"

Peristiwa tuturan terjadi pada malam hari di rumah. Angkasa sebagai penutur, ayah sebagai mitra tutur. Tuturan yang disampaikan bertujuan menyindir dan marah kepada ayah, karena sikapnya yang menutupi sesuatu dari anak-anaknya. Ketika semua anggota keluarga berkumpul di ruang tamu, dan ayah menegur anak-anaknya. Kemudian setelah mendengar pernyataan Aurora, Awan pun langsung meminta maaf karena merasa bersalah. Namun kedua kakaknya menyangkal agar Awan tidak perlu meminta maaf kepada Aurora. Lalu angkasa mulai kesal dan marah, berbicara dengan semua orang dengan maksud menyindir ayahnya karena sikapnya. Penyampaian tuturan dengan cara marah dan kesal. Tuturan yang disampaikan secara lisan. Penyampaian tuturan dengan kurang sopan, karena nada bicaranya yang kencang terhadap orang tua. Tuturan yang disampaikan berbentuk dialog. Tuturan tersebut merupakan bentuk tindak tutur direktif kritikan yang memiliki fungsi menyindir, terlihat dari tujuan tuturan tersebut Angkasa berbicara kepada seluruh anggota keluarga dengan maksud menyindir Ayah, karena menurut Angkasa semua yang ayahnya lakukan hanya menyangkal dan menyuruh semua orang di dalam keluarga senang tanpa perlu memikirkan kesedihan yang ada.

\section{Fungsi Memarahi}

Ayah: "Ini apa? Kamu tau Awan sedang rapuh dan dia butuh banyak tinggal di rumah, malah kamu ajak dia ke di lingkungan pergaulan kaтu. Кати liat dia salah bergaul, lalu pengaruhnya ke keluarga kita. Jelek!"

Peristiwa tuturan terjadi pada malam hari di rumah. Ayah sebagai penutur, dan Angkasa sebagai mitra tutur. Tuturan yang disampaikan bertujuan memarahi dan menegur Angkasa karna kelalaiannya mengajak Awan ke konser, yang pada saat itu Awan sedang terluka hingga di gips tangannya. Ketika semua anggota keluarga berkumpul di ruang tengah, ayah langsung berbicara mengenai kejadian perdebatan di acara pameran Aurora. Kemudian ayah marah dan menegur Angkasa karena perbuatannya yang lalai mengajak Awan pergi ke tempat konser yang Angkasa buat, hingga memberi pengaruh buruk kepada Awan hingga sikapnya. Lalu Ayah menyentak dan berkata "jelek" dengan maksud sikap Awan yang berubah setelah pergi ke konser dan mengenal dunia luar, berpengaruh buruk masuk ke dalam keluarga. Penyampaian tuturan dengan nada marah dan suara yang kencang. Tuturan yang disampaikan secara lisan. Penyampaian tuturan dengan tegas dan menyentak. Tuturan yang disampaikan berbentuk dialog. Tuturan tersebut merupakan bentuk tindak tutur direktif kritikan yang memiliki fungsi memarahi, terlihat dari tujuan tuturan tersebut Ayah memarahi Angkasa, karena menurut Ayah semua perilaku Awan yang berubah sering keluar malam dan susah dihubungi adalah berawal dari Angkasa mengajak Aurora yang ketika saat itu sedang sakit, pergi ke konser musik dan masuk ke dalam pergaulan yang salah.

\section{Bentuk Tindak Tutur Direktif Larangan}

Terdapat 6 data tuturan, yang digolongkan berdasarkan fungsi tindak tutur direktifnya seperti, fungsi melarang 3 data tuturan, dan fungsi mencegah 3 data tuturan.

\section{Fungsi Melarang}

Pak Rifai: "jangan ikut campur kamu uya, iya maksudnya perusahaan arsitektur itu” 
Peristiwa tuturan terjadi pada malam hari, di kantor. Pak Rifai sebagai penutur dan Uya sebagai mitra tutur. Tuturan yang disampaikan bertujuan untuk melaran Uya agar tidak ikut campur dalam pembicaraan Pak Rifai dengan Awan. Ketika Awan dan Pak Rifai berdebat mengenai tema maket yang dibuat Awan. Kemudia Pak Rifai salah menyebutkan suatu kata dan Uya memberitahu kata yang benarnya. Lalu Pak Rifai marah dan melarang Uya agar tidak ikut campur di dalam pembicaraan tersebut. Penyampaian tuturan dengan nada bicara marah, kesal dalam suasana yang serius. Tuturan yang disampaikan secara lisan. Penutur menunjukkan rasa kesalnya. Tuturan yang disampaikan berbentuk dialog. Tuturan tersebut merupakan bentuk tindak tutur direktif larangan yang memiliki fungsi melarang, terlihat dari tujuan tuturan tersebut Pak Rifai berbicara kepada Uya dan melarangnya ikut campur dalam pembicaraannya dengan Awan.

\section{Fungsi Mencegah}

Awan: "Jangan banyak-banyak satu aja."

Peristiwa tuturan terjadi pada siang hari di sebuah pasar. Awan sebagai penutur dan Kale sebagai mitra tutur. Tuturan yang disampaikan bertujuan mengingatkan dan mencegah Kale untuk tidak mengambil banyak-banyak makanan tersebut. Setelah keluar dari dari toko tersebut, Kale ingin meminta manisan tersebut dengan candaan. Kemudian Awan melarang Kale untuk meminta makanan tersebut, karena untuk cemilan Awan di rumah. Sambil bercanda kemudian Awan tersenyum dan memperbolehkan Kale mengambil manisan tersebut. Kemudian Awan mencegah Kale agar tidak mengambil banyak manisan tersebut cukup satu saja. Penyampaian tuturan dengan santai dan nada candaan. Tuturan yang disampaikan secara lisan. Penyampaian tuturan dengan bahasa yang baik, dengan mengingatkan. Tuturan yang disampaikan berbentuk dialog. Tuturan tersebut merupakan bentuk tindak tutur direktif larangan yang memiliki fungsi mencegah, terlihat dari tujuan tuturan tersebut Awan mencegah Kale untuk tidak mengambil dengan jumlah banyak makanan yang baru saja dibeli, Awan hanya memperbolehkan satu permen saja yang boleh diambil.

Hasil penelitian analisis bentuk dan fungsi tindak tutur direktif dalam film "Nanti Kita Cerita Tentang Hari Ini" disutradarai oleh Angga Dwimas Sasongko, dapat dimanfaatkan dan digunakan dalam pembelajaran Bahasa Indonesia di sekolah, salah satunya pada pembelajaran teks persuasi. Tindak tutur direktif memiliki keterkaitan dengan pembelajaran teks persuasi berdasarkan ciri kebahasaannya, yaitu untuk mempengaruhi pembaca atau mitra tutur agar melakukan suatu tindakan yang dimaksudkan oleh penutur atau penulis (Ismail, 2016). Teks persuasi merupakan sebuah teks yang dapat mempengaruhi dan membujuk pembaca untuk melakukan sesuatu sesuai dengan maksud penulis. Maka dari itu hasil penelitian ini, dimanfaatkan sebagai bahan ajar pembelajaran Bahasa Indonesia pada materi teks persuasi di kelas VIII Sekolah Menengah Pertama (SMP) dalam bentuk handout.

Penyusunan bahan ajar teks persuasi menyesuaikan dengan kompetensi dasar (KD) yang ada dalam silabus kelas VIII, serta kurikulum yang berlaku. Kompetensi Dasar yang akan digunakan adalah 3.14 Menelaah struktur dan kebahasaan teks persuasi yang berupa saran, ajakan, dan pertimbangan tentang berbagai permasalahan aktual (lingkungan hidup, kondisi sosial, san/atau keragaman budaya, dll) dari berbagai sumber yang didengar dan dibaca. 4.14 Menyajikan teks persuasi (saran, ajakan, arahan, dan pertimbangan) secara tulis dan lisan dengan memperhatikan struktur, kebahasaan, atau aspek lisan. Kemudian menentukan Indikator Pencapaian Kompetensi (IPK) yang hendak dicapai dalam pembelajaran teks persuasi dengan KD yang telah ditentukan, yaitu 3.14.1 Mengidentifikasi struktur dan kebahasaan teks persuasi yang bersumber dari penayangan film "Nanti Kita Cerita Tentang Hari Ini" yang disutradarai oleh Angga Dwimas Sasongko, 4.14.1 Membuat teks persuasi yang berdasarkan penayangan film "Nanti Kita Cerita Tentang Hari Ini” yang disutradarai oleh Angga Dwimas Sasongko dengan memperhatikan struktur dan unsur kebahasaannya, 4.14.2 Mempresentasikan hasil teks persuasi yang telah ditulis. 

Pemanfaatannya Sebagai Bahan Ajar Teks Persuasi - Joty Islamiati, Oding Supriadi, Sinta Rosalina DOI: https://doi.org/10.31004/edukatif.v4i1.1821

\section{KESIMPULAN}

Berdasarkan data penelitian yang telah diperoleh dan dianalisis mengenai bentuk dan fungsi tindak tutur direktif dalam percakapan pada film "Nanti Kita Cerita Tentang Hari Ini" yang disutradarai oleh Angga Dwimas Sasongko, ini ditemukan 131 data tuturan yang mengandung tindak tutur direktif, lalu digolongkan berdasarkan bentuk direktifnya yaitu bentuk perintah berjumlah 45 data tuturan, bentuk permintaan berjumlah 37 data tuturan, bentuk ajakan berjumlah 15 data tuturan, bentuk nasihat berjumlah 18 data tuturan yang memiliki fungsi direktif seperti, bentuk kritikan berjumlah 10 data tuturan, bentuk larangan berjumlah 6 data tuturan. Kemudian hasil penelitian dimanfaatkan sebagai bahan ajar teks persuasi di kelas VIII Sekolah Menengah Pertama (SMP), yang disusun dalam bentuk handout. Karena di dalam materi teks persuasi ciri kebahasaannya digunakan untuk mempengaruhi, membujuk pembaca atau pendengar agar melakukan sesuatu tindakan sesuai dengan maksud yang dimaksud penulis/pembicara. Ciri kebahasaan teks persuasi tersebut berkaitan dengan tujuan bentuk dan fungsi tindak tutur direktif, yang bertujuan mempengaruhi mitra tutur atau pendengarnya agar melakukan tindakan sesuai dengan maksud tuturan yang disampaikan oleh penutur. Penyusunan bahan ajar dalam bentuk handout bertujuan untuk meringkas materi agar mempermudah pada saat proses pembelajaran, disusun secara praktis dan menarik agar peserta didik mudah memahami materi. Proses penyusunan bahan ajar teks persuasi bersumber dari data hasil penelitian analisis bentuk dan fungsi tindak tutur direktif pada film "Nanti Kita Cerita Tentang Hari Ini", dan memperhatikan Kompetensi Dasar (KD) dan Indikator Pencapaian Kompetensi (IPK) berdasarkan silabus Bahasa Indonesia yang berlaku.

\section{DAFTAR PUSTAKA}

Agustina, A. C. Dan L. (2010). Sosiolinguistik: Perkenalan Awal. Rineka Cipta.

Azziz, F., Pratiwi, W. D., Bahasa, P., \& Karawang, U. S. (2021). Edukatif: Jurnal Ilmu Pendidikan Analisis Tindak Tutur Pada Film Riko The Series ( Kajian Pragmatik) Melalui Teks, Ko-Teks, Dan Konteks. 3(5), 3350-3360.

Bambang, I., Pratiwi, W. D., Nurhasanah, E., \& Karawang, U. S. (2021). Edukatif: Jurnal Ilmu Pendidikan Analisis Tindak Tutur Direktif Pada Novel Lajang-Lajang Pejuang Karya Endik Koeswoyo Dan Pemanfaatannya Dalam Pembelajaran Teks Pidato Di Smp. 3(6).

Bertasbih, C., \& Umam, K. C. (2017). Tindak Tutur Direktif Dalam Dialog Film "Ketika. Academia.Edu, 1-9. Http://Www.Academia.Edu/Download/52368810/Tindak_Tutur_Direktif.Pdf

Darwowidjojo, S. (2008). Psikolinguistik: Pengantar Pemahaman Bahasa Manusia (3rd Ed.). Yayasan Obor Indonesia.

Hirata, A. (N.D.). Tindak Tutur Ilokusi Dalam Novel Guru Aini Karya. 10(1), 19-33.

Islamiati, O., Arianti, R., Studi Pendidikan Bahasa Dan Sastra Indonesia, P., \& Rokania, S. (2020). Tindak Tutur Direktif Dalam Film Keluarga Cemara Sutradara Yandy Laurens Dan Implikasi Terhadap Pendidikan. Jurnal Pendidikan Rokania, V(2), 258-270.

Ismail, J. (2016). Tindak Tutur Dalam Film "Surat Kecil Untuk Tuhan" Karya Harris Nizam: Sebuah Tinjauan Pragmatik Dan Implikasinya Terhadap Pembelajaran Bahasa. Edukasi, 14(1), 411-422. Https://Doi.Org/10.33387/J.Edu.V14i1.185

Kesuma, T. M. (2007). Pengantar (Metode) Penelitian Bahasa. Caravatibooks.

Mahsun. (2012). Metode Penelitian Bahasa: Tahapan, Strategi, Metode, Dan Tekniknya. Rajawali Press.

Nuryatin, A., \& Artikel, I. (2015). Tindak Tutur Direktif Dalam Wacana Novel Trilogi Karya Agustinus Wibowo. Seloka: Jurnal Pendidikan Bahasa Dan Sastra Indonesia, 4(2), 78-85.

Rahardi, K. (2003). Berkenalan Dengan Ilmu Bahasa Pragmatik. In Malang: Dioma (5th Ed.). Dioma. 
486 Analisis Tindak Tutur Direktif dalam Film Nanti Kita Cerita Tentang Hari Ini (NKCTHI) dan Pemanfaatannya Sebagai Bahan Ajar Teks Persuasi - Joty Islamiati, Oding Supriadi, Sinta Rosalina DOI: https://doi.org/10.31004/edukatif.v4i1.1821

Rahma, A. N. (2018). Analisis Tindak Tutur Ilokusi Dalam Dialog Film Animasi Meraih Mimpi. Skriptorium, Vol. 2(2), 13-24.

Saputri, U. I., \& Rahmawati, L. E. (2020). Analisis Bentuk Tindak Tutur Direktif Dalam Dialog Film "Rembulan Tenggelam Di Wajahmu" Karya Tere Liye. Jurnal Kibasp (Kajian Bahasa, Sastra Dan Pengajaran), 3(2), 249-260.

Sudaryanto. (2015). Metode Dan Aneka Teknik Analisis Bahasa. Sanata Darma Apiti.

Sugiyono. (2016). Metode Penelitian: Kuanttatif, Kualitatif Dan R\&D. Alfabeta.

Sukmadinata Syaodih, N., \& Syaodih, E. (2012). Kurikulum Dan Pembelajaran. Revika Aditama 2012.

Wibowo, S. E. (2018). Etnopragmatik.

Widyawati, S. (2019). Analisis Tindak Tutur Dalam Film Duka Sedalam Cinta Karya Firman Syah. Https://Doi.Org/10.31227/Osf.Io/Zhpu7

Yaumi, M. (2018). Media Dan Teknologi Pembelajaran. Prenada Media Group (Divisi Kencana). 